\title{
Predictive Factors for the Suppression of Fusarium Wilt of Tomato in Plant Growth Media
}

\author{
Celia Borrero, M. Isabel Trillas, José Ordovás, Julio C. Tello, and Manuel Avilés
}

\begin{abstract}
First, third, and fifth authors: Department Ciencias Agroforestales, Universidad de Sevilla, Ctra. Utrera, Km. 1. 41013 Sevilla, Spain; second author: Department Biología Vegetal, Universitat de Barcelona, Avda Diagonal, 645, 08028 Barcelona, Spain; and fourth author: Department Producción Vegetal, Universidad de Almería, Ctra. Sacramento, s/n, 04120 La Cañada de San Urbano, Almería, Spain.
\end{abstract}

Accepted for publication 2 June 2004.

\begin{abstract}
Borrero, C., Trillas, M. I., Ordovás, J., Tello, J. C., and Avilés, M. 2004. Predictive factors for the suppression of Fusarium wilt of tomato in plant growth media. Phytopathology 94:1094-1101.

Fusarium wilts are economically important diseases for which there are no effective chemical control measures. However, biological control and fertility management are becoming efficient alternatives for controlling this disease. Growth media formulated with composts that are able to suppress Fusarium wilt of tomato provide a control system that integrates both strategies. The aim of this study was to predict Fusarium wilt suppression of growth media using abiotic and biotic variables. Grape marc

were in a pH range of 6.26 to 7.97 . Both composts had high $\beta$-glucosidase activity. When $\mathrm{pH}$ and $\beta$-glucosidase activity were taken into account as predictive variables, more than $91 \%$ of the variation in severity of Fusarium wilt was explained. This relationship illustrates the effect of nutrient availability and the degree of microbiostasis, two key factors in this pathosystem. Microbial populations involved in suppressiveness were cellulolytic and oligotrophic actinomycetes, fungi, and the ratios cellulolytic actinomycetes/cellulolytic bacteria, oligotrophic bacteria/copiotrophic bacteria, and oligotrophic actinomycetes/oligotrophic bacteria. Based on community level physiological profiles, different community structures were evident among growth media evaluated.
\end{abstract} compost was the most effective medium used to suppress Fusarium wilt. Cork compost was intermediate, and light peat and expanded vermiculite were the most conducive growth media. The growth media evaluated
Additional keywords: Fusarium oxysporum f. sp. lycopersici, Lycopersicon esculentum, microbial activity.
Fusarium wilt diseases, caused by pathogenic formae speciales of the soil-inhabiting fungus Fusarium oxysporum (Sacc.) W. C. Snyder \& H. N. Hans., cause severe losses in a wide variety of crop plants, including tomato (Lycopersicon esculentum Mill.). This pathogen occurs throughout most tomato-growing areas and devastates the crop. Fusarium-resistant cultivars have been available for decades and provide some degree of control; however, the occurrence and development of new pathogenic races is a continuing problem. There are no commercially acceptable tomato cultivars with adequate resistance (27). In addition, the resurgent interest in planting heirloom and other susceptible tomato cultivars has increased the incidence of Fusarium wilt. Effective soil fungicide treatments for this disease also are unavailable. Difficulties in controlling Fusarium wilt have stimulated the search for biocontrol systems. The nature of soils and composts that are suppressive to Fusarium wilt is the result of complex interactions between the abiotic characteristics of the media and microbial populations $(1,2,21,60)$. Numerous biocontrol agents have been identified in these soils and composts $(21,60)$. Unfortunately, the introduction of biocontrol agents has provided inconsistent results (59). Growth media formulated with composts such as hardwood bark $(9,55)$, pine bark $(8,42,44)$, poplar bark $(16)$, wood shavings (8), cork (54), grape marc (54), olive pumice (44), cattle manure (45), sewage sludges $(11)$, and vermicompost $(16,51,52)$ can suppress Fusarium wilt. Several of these have been used successfully for consistent biological control, particularly for containerized crops $(21,22)$. The microbiological nature of Fusarium wilt-suppressiveness for most of these compost-amended growth media

Corresponding author: M. Avilés; E-mail address: aviles@us.es

Publication no. P-2004-0721-01R

(C) 2004 The American Phytopathological Society has been demonstrated $(8,9,11,16,22,42,43,45,47,51,54,55)$. The role of nutritional factors in wilt-suppressiveness also has been suggested $(11,22,42,55)$. For some composts, it has been demonstrated that fungitoxic substances are not involved $(43,45,47,51)$.

The main purpose of this study was to determine the relationship between biotic and abiotic properties of growth media and the severity of Fusarium wilt in order to predict disease suppressiveness of growth media. In addition, nutrient availability, nutrient status of plants, and microbial diversity were evaluated at the conclusion of the experiments in order to understand possible mechanisms involved in the suppressive phenomena. For this purpose, two Fusarium-suppressive composts, which can be used as plant growth media, were compared with two standard growth media.

\section{MATERIALS AND METHODS}

Plant growth media. Two residues from agricultural and industrial wastes were composted and evaluated for Fusarium wilt suppression: cork compost (CC) from cork (Quercus suber L.) production and grape marc compost (GMC) from the alcoholproducing industry (grape skins, seed, and stems). Both wastes were composted as described elsewhere (54). Composts were compared with Sphagnum light peat (P) (Klasmann, Valinex, Palleter, Spain) and expanded vermiculite (V) (Vermiculita y derivadas, Gijón). Peat was neutralized with $\mathrm{CaCO}_{3}$ at $4 \mathrm{~g} / \mathrm{liter}$. To determine the role of microflora in suppression, the two composts also were heated to $60^{\circ} \mathrm{C}$ for 6 days, (CC-60 and GMC-60).

Assessment of disease severity. Disease-suppressive properties of plant growth media were measured by a Fusarium wilt bioassay described elsewhere (11). To standardize initial conditions, the growth media were incubated at a water tension of $1,000 \mathrm{~Pa}$ (adjusted for weight) for 14 days at $25^{\circ} \mathrm{C}$. Liquid culture $(500 \mathrm{ml}$ 
of 1\% malt extract; Sigma-Aldrich, St Louis) of Fusarium oxysporum f. sp. lycopersici race 2, isolate RAF 70 obtained from an infected tomato plant (FOL-2), was prepared and grown with continuous agitation $(130 \mathrm{rpm})$ for 10 days at $25^{\circ} \mathrm{C}$. Conidia were recovered by centrifugation at $5,000 \mathrm{rpm}$ for $15 \mathrm{~min}$ (Selecta Medifriger BL-S, Abrera, Spain) and rinsed twice with sterile distilled water. The concentration of conidia was determined with a hemocytometer. The six plant growth media were infested with FOL-2 (10 microconidia/ $\mathrm{cm}^{3}$ of plant growth medium), mixed vigorously, and poured into 9 -cm-diameter plastic pots $\left(330 \mathrm{~cm}^{3}\right.$ volume). Pots of growth media without FOL-2 were prepared as controls. Four tomato seedlings (one- to two-true-leaf stage) grown in sterile vermiculite were transplanted into each pot. Plants were irrigated as needed and fertilized with a nutrient solution containing Peter's foliar feed 27-15-12 at 0.5 g/liter (Scotts, Heerlen, The Netherlands), $\mathrm{CaCl}_{2}$ at $0.6 \mathrm{~g} /$ liter, and $\mathrm{MgSO}_{4} \cdot 7 \mathrm{H}_{2} \mathrm{O}(\mathrm{pH} 5.68)$ at $0.696 \mathrm{~g} /$ liter. Plants were grown in a growth chamber $\left(25^{\circ} \mathrm{C}\right.$, photosynthetically active radiation (PAR) intensity $280 \mu \mathrm{E} / \mathrm{m}^{2} \cdot \mathrm{s}$, photoperiod $16 \mathrm{~h}$ light and $8 \mathrm{~h}$ dark, and $60 \%$ relative humidity). Bioassays were repeated at least three times with four plants per pot and five pots per treatment. Treatments were arranged in a randomized block design. Disease severity was monitored at 2-day intervals for 25 days after planting, and was scored based on a symptom severity scale where $0=$ asymptomatic plants, $1=$ weakly infected plants ( $\leq 50 \%$ of leaves chlorotic or wilted), $2=$ highly infected plants $(>50 \%$ of leaves wilted but plants not dead), and 3 = dead plants (11). Disease severity was expressed as proportion of the maximum possible disease severity. At each disease assessment, the mean of disease severity per pot was calculated. The area under the disease progress curve standardized (AUDPCs) per pot was calculated by disease severity integrated between symptoms onset and bioassay final time and dividing by the total duration (days) of the epidemic in each bioassay, in order to compare the various bioassays, which had a variety of epidemic durations. At the end of the bioassays, mean values per pot (four plants) of the relative length of the stem with brown xylem (RLSBX), and the fresh and dry weight of leaves and stems means per pot were recorded. These values per pot were considered as replicates for each observed variable.

Physical and physicochemical properties of growth media. The bulk density (BD) for the plant growth media was determined according to De Boot et al. (13). Electrical conductivity (EC) and $\mathrm{pH}$ of media were measured in a water extract $(2: 1, \mathrm{vol} / \mathrm{vol})$ as described by Bunt (6) and Gabriëls et al. (15), respectively. Physical and chemical variables of the growth media were determined at the beginning of the bioassays. The $\mathrm{pH}$ also was measured at the end of each bioassay. Three samples were analyzed for each growth medium.

Nutrient availability and nutrient status of plants. Plant growth media samples $(50 \mathrm{~g})$ were collected from the pots and extracted with $0.5 \mathrm{M}$ ammonium acetate ( $\mathrm{pH} 4.65)$. Plant samples $(0.25 \mathrm{~g}$ dry weight $)$ from all treatments were incinerated at $550^{\circ} \mathrm{C}$ for $8 \mathrm{~h}$ and dissolved in $20 \mathrm{ml}$ of $1 \mathrm{~N} \mathrm{HCl}$, filtered as necessary, and stored at $4{ }^{\circ} \mathrm{C}$ until analysis. Calcium, magnesium, iron, copper, manganese, and zinc were determined by atomic absorption spectroscopy (63) and sodium and potassium were analyzed by atomic emission spectrometry (63). Phosphorous was measured with colorimetry (37), nitrate (plant growth media) with reflectometry (RQ flex Merck, Darmstadt, Germany) (50), and boron (plants) with colorimetry (31). Total nitrogen in plants was measured with Kjeldahl digestion, modified to include nitrates, and ammonium subsequently was determined with colorimetry (36). All analyses were performed with three samples for plants and two samples of plant growth media from one of the three bioassays, at the end of the experiment.

Biological characteristics of growth media. All determinations were performed in incubated growth media at the beginning of bioassays, except for microbial diversity.
Microbial biomass. Three techniques were used to assess microbial biomass: (i) phosphates from phospholipids (10), with digestion as described by Van Veldhoven and Mannaerts (57) and phosphate determination with colorimetry (37); (ii) fumigationextraction, based on the estimation of cell carbon by extraction with saline solution of fumigated and nonfumigated samples and their conversion to biomass (46); and (iii) acridine orange direct counting (AODC) technique, which was performed by counting cells from an aqueous extraction with an epifluorescence microscope (30). The aqueous extraction was filtered through $0.2-\mu \mathrm{m}$ pore size black polycarbonate membranes (Isopore, Millipore Iberica S.A., Madrid, Spain). Counting was performed at $\times 1,250$ with a minimum of 400 cells per filter. Controls were counted also in sterile water. Three samples were analyzed for each plant growth medium, except for those that were heated.

Microbial activity. Microbial activity was estimated by measuring $\beta$-glucosidase activity. This method is based on colorimetric determination of the $p$-nitrophenol released by $\beta$-glucosidase when the plant growth medium was incubated with $p$-nitrophenil$\beta$-D-glucoside ( $\mathrm{pH}$ 6.0). The $p$-nitrophenol released was extracted by filtration and determined colorimetrically. $\beta$-Glucosidase activity was measured according to Bandick and Dick (4). Two samples were analyzed for each plant growth medium.

Microbial diversity. The density of cultivable groups of bacteria and fungi associated with biocontrol phenomena was determined by dilution plating on semiselective media according to Tuitert et al. (56) with modifications. Samples were taken from the rhizosphere at the end of bioassays. Plant growth media (5 to $10 \mathrm{~g}$ ) were suspended in $250 \mathrm{ml}$ of $0.1 \%$ sodium pyrophosphate. The suspension was shaken and 10-fold dilution series were prepared with $0.1 \%$ water agar. Suspensions were pipetted onto three plates per culture medium and dilution. Four or five dilutions per series were placed on plates. For isolation of copiotrophic bacteria, Bacillus spp., fluorescent Pseudomonas spp., oligotrophic and cellulolytic bacteria, and actinomycetes, $100 \mu \mathrm{g}$ of cycloheximide was substituted for benomyl (Energía e Industrias Aragonesas, S.A., Madrid) at $10 \mu \mathrm{g} / \mathrm{ml}$ and Previcur (Propamocarb, $72.2 \%$, Schering, Alcácer, Spain) at $0.3 \mu \mathrm{l} / \mathrm{ml}$. Fungal counts were made on potato dextrose agar amended with Tergitol-7 (Fluka Chemie AGB, Buchs, Switzerland) at 1,000 ppm and $50 \mu \mathrm{g}$ of oxytetracycline hydrochloride (Sigma-Aldrich) (10). Data for population density was normalized by natural log (Ln) transformations. Analyses were performed twice with one sample per each control and each infested plant growth medium from each of the two bioassays.

Community level physiological profiles. Eco-microplates (Biolog Inc., Hayward, CA) were used to determine differences in physiological abilities of the microbial communities from different plant growth media and the similarities between these communities and the pathogen. The microplates contained 96 wells with 31 carbon sources plus control, with three replicates each, as has been proposed for community characterization in environmental samples (25). The growth media extraction method was performed according to Insam et al. (26). Population cell density was determined by AODC to standardize the inoculum density. The density of FOL-2 conidia in suspension was determined by hemocytometer. Five eco-microplates were inoculated for plant growth medium suspensions and three for FOL-2 conidial suspension. The microplates were incubated in darkness at $25^{\circ} \mathrm{C}$ for 5 days. Color formation was measured with a microplate reader (Labsystem Multiskan MS, Helsinki, Finland) at $590 \mathrm{~nm}$ and readings were made at 12-h intervals. For the analysis, the average absorbance of the control wells in each plate was subtracted from that of wells containing the same $\mathrm{C}$-source. Negative values were considered as zero. Microbial community diversity was calculated with these data using Shannon (48) and Gini (19) indices to compare functional diversity of microbial communities. For further analysis of Biolog data, a Riemann's sum for each C-source was calculated from all readings taken during the 5 days of incubation (49). The 
transformed data were subjected to principal component analysis (PCA) (17), and distances in Euclidean space from the first five principal components were calculated (24).

Statistical analysis. Data collected from all trials were analyzed with Statgraphics Plus (version 5.1; Statistical Graphics Corp., Rockville, MD). The effect of growth medium on AUDPCs, $\mathrm{pH}, \mathrm{EC}, \mathrm{BD}$, nutrient availability, nutrient status in plants, and biological characteristics of container medium were analyzed with analysis of variance. Significant means were compared by Tukey's whole significant difference test $(P=0.05)$. Overall relationships between AUDPCs and continuous measured variables were analyzed with regression analysis.

\section{RESULTS}

Suppressiveness of plant growth media. Fusarium wilt was suppressed most effectively with GMC, with more than a $92 \%$ reduction in AUDPCs and RLSBX compared with peat or vermiculite. Media CC, GMC-60, and CC-60 were intermediate, and $\mathrm{P}$ and $\mathrm{V}$ were the most conducive growth media (Fig. 1A). The heated composts had reduced suppressive ability; however, GMC60 maintained moderate levels of suppressiveness compared with $\mathrm{P}$ and $\mathrm{V}$ (Fig. 1A and B). Medium CC-60 was not different from $\mathrm{P}$ for disease severity measured by RLSBX (Fig. 1B). At an

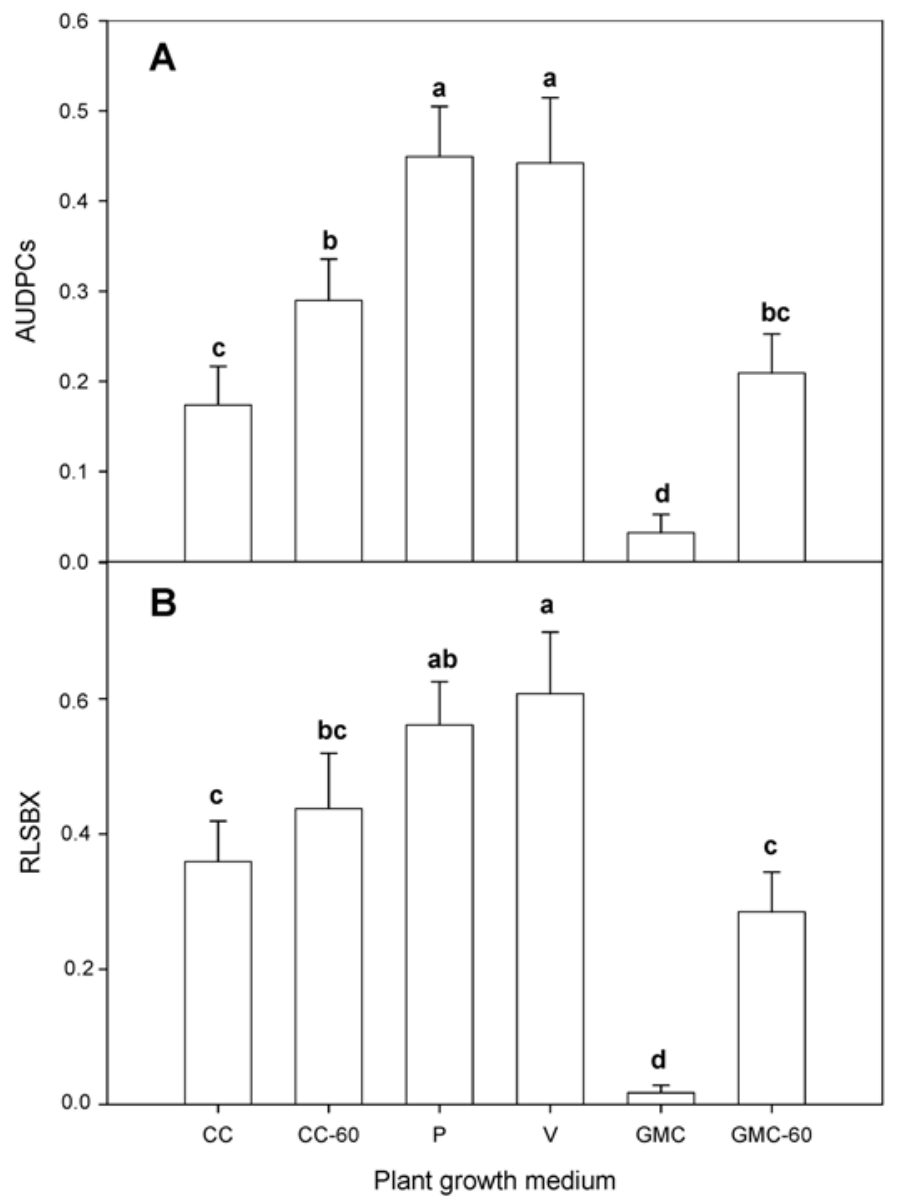

Fig. 1. A, Standardized area under disease progress curve (AUDPCs) and B, relative length of stem with brown xylem (RLSBX) for tomato plants in six growth media: CC, composted cork; CC-60, heated composted cork; P, peat; $\mathrm{V}$, vermiculite; GMC, grape marc compost; and GMC-60, heated grape marc compost. Disease severity scale was $0=$ asymptomatic plants, $1=\leq 50 \%$ affected leaves, $2=>50 \%$ affected leaves, and $3=$ dead plants. Plant growth media were infested with Fusarium oxysporum f. sp. lycopersici race 2 at a dose of $1 \times 10^{5}$ microconidia/ $\mathrm{cm}^{3}$. Data for AUDPCs and RLSBX were transformed for analysis with the arcsine $\sqrt{ } \mathrm{x}$. Bars with the same letter are not significantly different according to Tukey's test at $P<0.05$. Standard error of the mean is indicated by vertical line. inoculum concentration of $1 \times 10^{4}$ microconidia $/ \mathrm{cm}^{3}$ of plant growth medium, the AUDPCs were similar to that for $1 \times 10^{5}$ microconidia $/ \mathrm{cm}^{3}$ of plant growth medium but with lower disease levels (data not shown). The best correlation between measured disease-related variables and the fresh and dry weight of leaves and stems (data not shown) was between AUDPCs and the square root of fresh weight $\left(R^{2}=72.49, P<0.001\right)$. RLSBX and the square root of dry weight had the lowest correlation $\left(R^{2}=20.94\right.$, $P<0.001)$. Consequently, AUDPCs was selected to make further correlation analysis with the different measured variables. None of the plants grown in the six noninfested control growth media developed symptoms of Fusarium wilt.

Physical, chemical, and biological properties of growth media at the beginning of bioassays. The BD was higher in both composts than in peat and vermiculite (Table 1). The GMC medium had the highest $\mathrm{pH}$. After heat treatment, the $\mathrm{pH}$ rose transiently for both composts. Vermiculite and peat had the lowest EC, followed by GMC and CC. The CC medium had the highest $\beta$-glucosidase activity, followed by GMC; when heated, both composts had enzyme activity similar to that of peat (Table 2). Similar trends were obtained from biomass determinations: phosphate and fumigation extraction enabled separation of $\mathrm{V}$ from GMC, and AODC differentiated the two composts from each other and from $\mathrm{P}$ and $\mathrm{V}$ (Table 2). No significant relationships were observed among parameters $(\mathrm{BD}, \mathrm{pH}, \mathrm{EC}, \beta$-glucosidase activity, PBP, FE biomass, and AODC) studied before the bioassay and AUDPCs. However when the $\mathrm{pH}$ and the $\beta$-glucosidase activity were taken into account as predictive variables (multiple linear regression), more than $91 \%$ of the variation in AUDPCs was explained ( $P<0.05$; Fig. 2).

The results of the PCA performed for community level physiological profiles (CLPPs) on the whole community Biolog pattern from growth media and FOL-2 are depicted graphically (Fig. 3). Based on the scatter in the coordinate score, there was a clear separation between growth media samples along the PC1 axis $(P<$ $0.05)$, accounting for $77 \%$ of the variance in the data. There also was a clear separation between GMC and the other growth media along the PC2 axis $(P<0.05)$. The PC2 explained $16 \%$ of the variance in the data. Among the growth media, there were different C-metabolic profiles and, therefore, different community structures. The first five principal components explained $98 \%$ of the variance in the data. Distances in Euclidean space, formed by the first five principal components between FOL-2 and growth media whole community patterns, revealed the shortest distance to be between FOL-2 and CC. This means that the $\mathrm{CC}$ microbial community had the catabolic potential most qualitatively similar to FOL-2. Diversity indices, however, revealed that CC had the lowest functional diversity, while GMC had a higher Gini index than P, with Shannon indices being similar (Table 3).

Nutrient availability, nutrient status of plants, and rhizosphere microbial diversity at the end of the bioassays. The

TABLE 1. Physical and physicochemical properties of plant growth media evaluated in bioassays ${ }^{\mathrm{w}}$

\begin{tabular}{lcccc}
\hline $\begin{array}{l}\text { Plant growth } \\
\text { medium }^{\mathrm{x}}\end{array}$ & $\begin{array}{c}\text { Bulk density } \\
\left(\mathrm{g} / \mathrm{cm}^{3}\right)^{\mathrm{y}}\end{array}$ & $\mathrm{pH}^{\mathrm{y}}$ & $\mathrm{pH}^{\mathrm{z}}$ & $\begin{array}{c}\text { Electrical conductivity } \\
(\mathrm{mS} / \mathrm{cm})^{\mathrm{y}}\end{array}$ \\
\hline $\mathrm{CC}$ & $0.22 \mathrm{~b}$ & $6.26 \mathrm{~d}$ & $5.74 \mathrm{~b}$ & $1.53 \mathrm{a}$ \\
$\mathrm{CC}-60$ & $\mathrm{ND}$ & $6.71 \mathrm{c}$ & $5.85 \mathrm{~b}$ & $1.62 \mathrm{a}$ \\
$\mathrm{P}$ & $0.09 \mathrm{c}$ & $6.28 \mathrm{~d}$ & $5.79 \mathrm{~b}$ & $0.24 \mathrm{c}$ \\
$\mathrm{V}$ & $0.13 \mathrm{c}$ & $6.48 \mathrm{dc}$ & $6.07 \mathrm{~b}$ & $0.05 \mathrm{c}$ \\
GMC & $0.41 \mathrm{a}$ & $7.35 \mathrm{~b}$ & $6.72 \mathrm{a}$ & $1.00 \mathrm{~b}$ \\
GMC-60 & ND & $7.97 \mathrm{a}$ & $6.86 \mathrm{a}$ & $0.94 \mathrm{~b}$ \\
\hline
\end{tabular}

${ }^{w}$ Within each column, values with different letters are significantly different $(P<0.05)$ according to Tukey's test. ND = not determined.

${ }^{x}$ CC, composted cork; CC-60, heated composted cork; P, peat; V, vermiculite; GMC, grape marc compost; GMC-60, heated grape marc compost.

y At beginning of bioassay.

z At end of bioassay. 
GMC medium maintained a high $\mathrm{pH}$ at the end of bioassays and heat treatment did not affect the final $\mathrm{pH}$ for either CC or GMC (Table 1). During the bioassay, plants showed no symptoms of nutrient deficiency. However, at the end of the bioassay, nutrient availability was different in infested growth media (Table 4). Nutrient status of plants also differed in infested media (Table 5). In the $\mathrm{pH}$ range used in this study, growth media per se conditioned the availability of nutrients, even when the same fertigation was used.

Infested $\mathrm{P}$ and $\mathrm{V}$ had higher levels of $\mathrm{Cu}$ than either compost. Infested $\mathrm{P}$ and $\mathrm{V}$ had the lowest levels of $\mathrm{Na}, \mathrm{Ca}, \mathrm{Fe}$, and $\mathrm{Mn}$. The GMC showed the highest levels of $\mathrm{Na}, \mathrm{Ca}, \mathrm{Mg}, \mathrm{P}$, and $\mathrm{K}$ (Table 4). There was a significant positive correlation between the availability of $\mathrm{Cu}$ for all growth media and the AUDPCs in infested pots (Table 6) and a negative correlation between the availability of $\mathrm{Na}$ and $\mathrm{Ca}$ for all growth media and the AUDPCs (Table 6). The nutrient status of plants in unheated GMC had the lowest level of $\mathrm{N}$ and $\mathrm{Mn}$ (Table 5). Plants grown in infested vermiculite had the highest level of $\mathrm{Na}$. Plants grown in GMCs had higher levels of $\mathrm{K}$ than those grown in $\mathrm{CC}$, peat, and vermiculite (Table 5). Based on chemical analysis, plants grown in infested peat had higher levels of N, P, and Fe and lower levels of $\mathrm{Mg}$ than those grown in $\mathrm{CC}$ and GMC (Table 5). Plants grown in

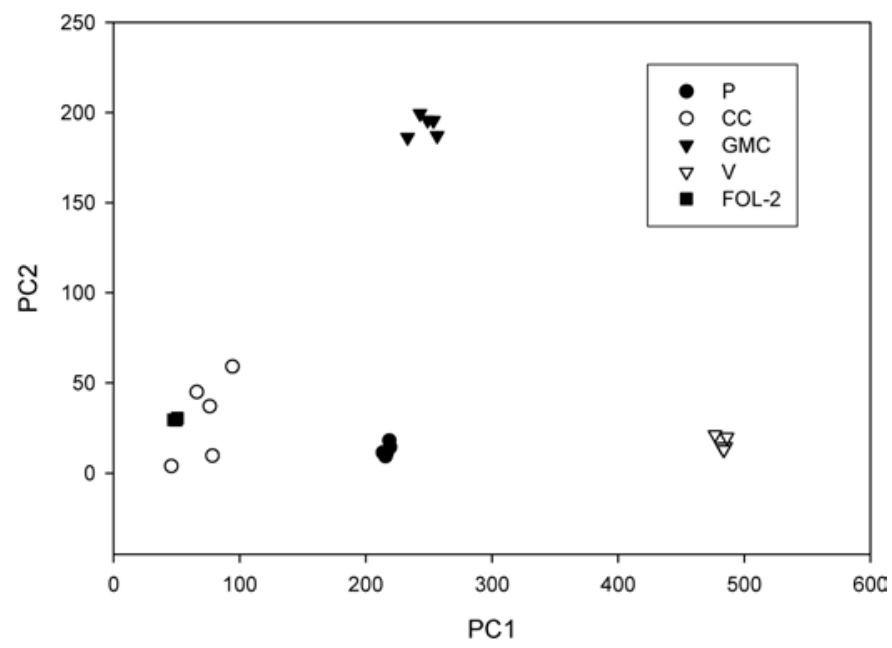

Fig. 3. Ordinate plot of principal components (PC1 and $\mathrm{PC} 2$ ) of microbial communities of four plant growth media at beginning of bioassay and Fusarium oxysporum f. sp. lycopersici (FOL-2) according to Biolog pattern. CC, composted cork; P, peat; V, vermiculite; and GMC, grape marc compost.

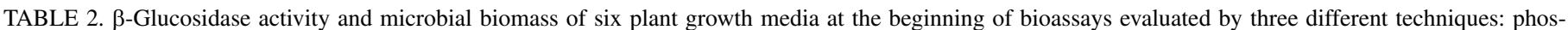
phate biomass from phospholipids (PBP), fumigation extraction (FE), and acridine orange direct counting $(\text { AODC })^{\mathrm{y}}$

\begin{tabular}{|c|c|c|c|c|}
\hline Plant growth medium ${ }^{2}$ & $\beta$-Glucosidase ( $\mu$ g hydrolized $p$-nitrophenol $/ \mathrm{cm}^{3}$ ) & PBP $\left(\mu\right.$ moles $\left.\mathrm{P} / \mathrm{cm}^{3}\right)$ & FE biomass ( $\mu$ moles $\mathrm{C} / \mathrm{g})$ & AODC (number of cells) \\
\hline $\mathrm{CC}$ & $172.95 \mathrm{a}$ & $0.032 \mathrm{ab}$ & $251.68 \mathrm{ab}$ & $4.44 \times 10^{6} \mathrm{a}$ \\
\hline CC-60 & $54.96 \mathrm{c}$ & ND & ND & ND \\
\hline $\mathrm{P}$ & $35.07 \mathrm{c}$ & $0.014 \mathrm{ab}$ & $272.11 \mathrm{ab}$ & $3.73 \times 10^{5} \mathrm{c}$ \\
\hline $\mathrm{V}$ & $0.59 \mathrm{~d}$ & $0.006 \mathrm{~b}$ & $158.36 \mathrm{~b}$ & $8.44 \times 10^{4} \mathrm{c}$ \\
\hline GMC & $110.04 \mathrm{~b}$ & $0.036 \mathrm{a}$ & $475.71 \mathrm{a}$ & $1.94 \times 10^{6} \mathrm{~b}$ \\
\hline GMC-60 & $40.34 \mathrm{c}$ & ND & ND & ND \\
\hline
\end{tabular}

y Within each column, values followed by different letters are significantly different based on Tukey's test at $P<0.05$. ND $=$ not determined.

${ }^{\text {z }}$ CC, composted cork; CC-60, heated composted cork; P, peat; V, vermiculite; GMC, grape marc compost; GMC-60, heated grape marc compost.

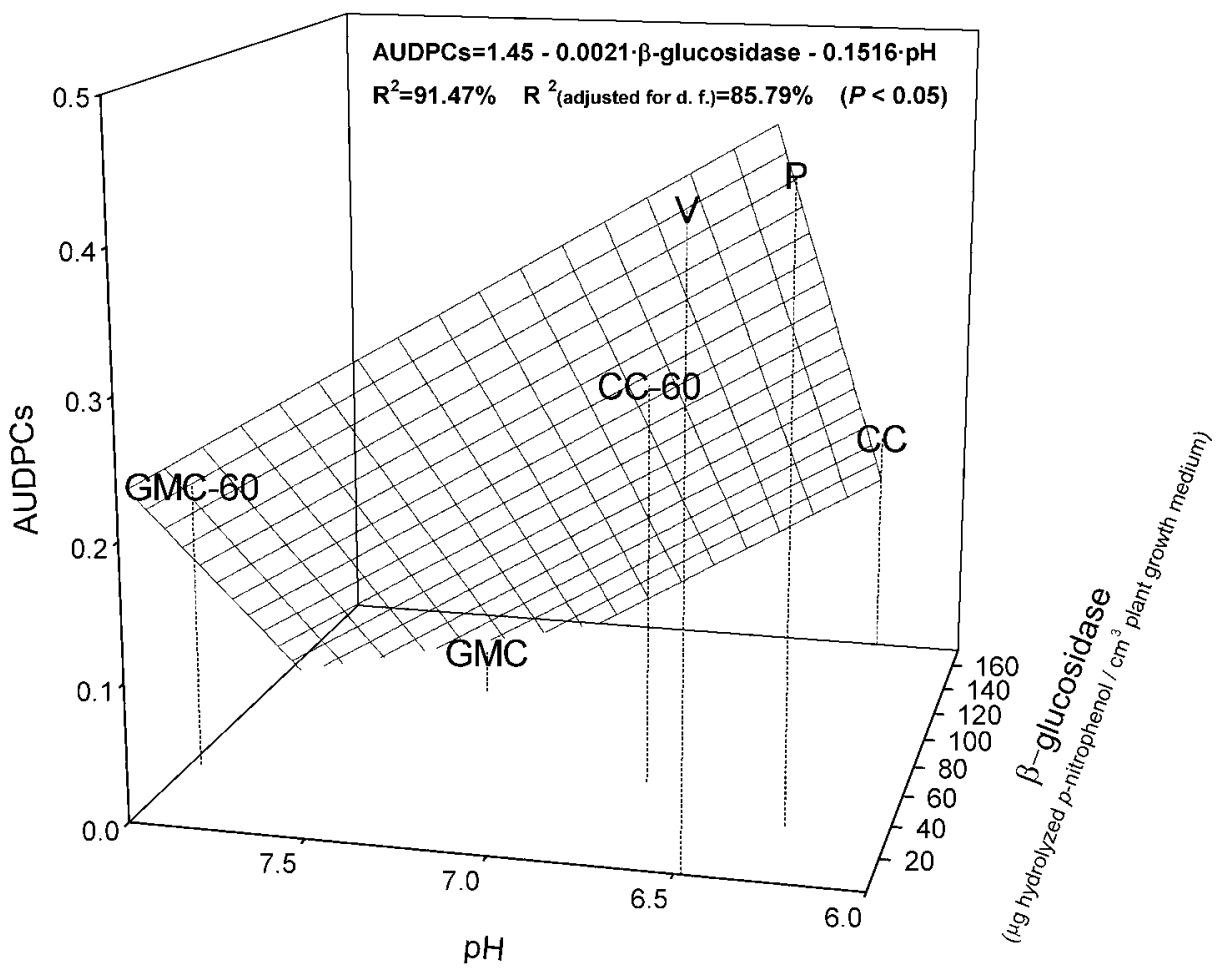

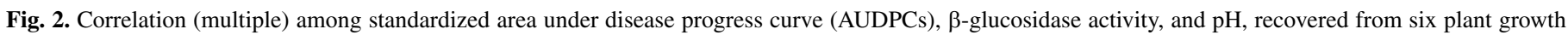

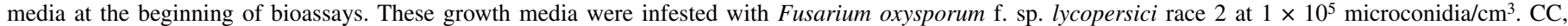

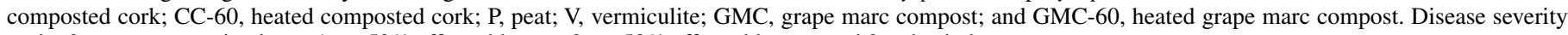
scale: $0=$ asymptomatic plants, $1=\leq 50 \%$ affected leaves, $2=>50 \%$ affected leaves, and $3=$ dead plants 
GMC had lower levels of $\mathrm{Cu}$ than $\mathrm{V}$ and peat (Table 5). The levels of $\mathrm{Fe}, \mathrm{N}, \mathrm{Cu}, \mathrm{P}$, and $\mathrm{Na}$ in plants grown in the various growth media were positively correlated with the AUDPCs (Table 6).

Among noninfested media, $\mathrm{P}$ and $\mathrm{V}$ had the lowest populations of Bacillus spp. and oligotrophic actinomycetes (Table 7). Medium $\mathrm{CC}$ had the highest population of fluorescent Pseudomonas spp., while GMC had the highest number of oligotrophic actinomycetes. The heat-treated CC and GMC media had higher populations of Bacillus spp. and lower densities of fluorescent Pseudomonas spp. than unheated. There also was a reduction in the population densities of oligotrophic actinomycetes and fungi for GMC-60.

Populations of copiotrophic bacteria, cellulolytic bacteria, and oligotrophic bacteria were not significantly different among infested growth media (Table 7). The population densities of Bacillus spp. remained high for GMC in the presence of the pathogen. Numbers of oligotrophic and cellulolytic actinomycetes and fungi were highest in infested GMC (Table 7). These three populations of microorganisms were negatively correlated with AUDPCs (Table 8). Vermiculite had the lowest number of oligotrophic actinomycetes (Table 7). A negative correlation was found between the oligotrophic actinomycetes/oligotrophic bacteria ratio and AUDPCs (Table 8). The ratios for cellulolytic actinomycetes/ cellulolytic bacteria and oligotrophic bacteria/copiotrophic bacteria also were negatively correlated with AUDPCs (Table 8).

TABLE 3. Gini (1-G) and Shannon $\left(\mathrm{H}^{\prime}\right)$ diversity indices of microbial communities of plant growth media at beginning of bioassay according to Biolog pattern

\begin{tabular}{lcc}
\hline & \multicolumn{2}{c}{ Diversity index $^{\mathrm{z}}$} \\
\cline { 2 - 3 } Plant growth medium $^{\mathrm{y}}$ & $1-\mathrm{G}$ & $\mathrm{H}^{\prime}$ \\
\hline $\mathrm{CC}$ & $0.492 \mathrm{c}$ & $2.950 \mathrm{~b}$ \\
$\mathrm{P}$ & $0.637 \mathrm{~b}$ & $3.181 \mathrm{a}$ \\
$\mathrm{V}$ & $0.714 \mathrm{a}$ & $3.254 \mathrm{a}$ \\
GMC & $0.697 \mathrm{a}$ & $3.124 \mathrm{a}$ \\
\hline
\end{tabular}

y CC, composted cork; P, peat; V, vermiculite; GMC, grape marc compost.

${ }^{\mathrm{z}}$ Within each column, values followed by different letters are significantly different based on Tukey's test at $P<0.05$.

\section{DISCUSSION}

Based on the correlation between AUDPCs and plant fresh weight, Fusarium wilt was the main growth-limiting factor in infested growth media. This relationship has been demonstrated in studies on Fusarium wilt of tomato and basil $(11,40,45)$. Our results are consistent with those of other studies where peat was found to be a conducive plant growth medium for several Fusarium wilts, whereas successful disease suppression was provided by composts $(8,9,11,16,42,44,45,52)$. Biocide treatment applied to composts eliminated or reduced disease suppression $(9,11,16,45,55)$. In the present study, GMC medium maintained a moderate disease suppression despite heat treatment $\left(60^{\circ} \mathrm{C}\right)$, and the same occurred for $\mathrm{CC}$, albeit at a lower level.

The beneficial effects of high $\mathrm{pH}$ in reducing disease caused by Fusarium spp. in a number of crops, including tomato, are well established $(28,61)$. The growth media evaluated in this study were within a $\mathrm{pH}$ range of slightly acid (6.26) to slightly alkaline

TABLE 6. Correlation (simple) among standardized area under the disease progress curve (AUDPCs) and nutrient availability of plant growth media (milligrams of nutrients per cubic centimeters of plant growth medium) and tomato plants (milligrams of nutrients per gram of dry weight) at the end of the bioassay

\begin{tabular}{lccl}
\hline AUDPCs, element $^{\mathrm{y}}$ & $R^{2}$ & $P^{\mathrm{z}}$ & \multicolumn{1}{c}{ Equation } \\
\hline Plant growth media & & & \\
$\mathrm{Na}$ & 81.36 & $*$ & AUDPCs $=0.54-2.04 \times \mathrm{Na}$ \\
$\mathrm{Cu}$ & 77.23 & $*$ & AUDPCs $=-0.006+12.96 \times \sqrt{\mathrm{Cu}}$ \\
$\mathrm{Ca}$ & 77.16 & $*$ & AUDPCs $=0.58-0.20 \times \mathrm{Ln}(\mathrm{Ca})$ \\
$\mathrm{Tomato} \mathrm{plants}$ & & & \\
$\mathrm{Fe}$ & 98.54 & $* * *$ & AUDPCs $=0.65-0.06 / \mathrm{Fe}$ \\
$\mathrm{N}$ & 97.24 & $* *$ & AUDPCs $=\mathrm{e}^{(1.29-45.14 / \mathrm{N})}$ \\
$\mathrm{Cu}$ & 93.01 & $* *$ & AUDPCs $=\mathrm{e}^{(1.85-0.05 / \mathrm{Cu})}$ \\
$\mathrm{P}$ & 87.69 & $* *$ & AUDPCs $=\mathrm{e}^{(5.56-155.53 / \mathrm{P})}$ \\
$\mathrm{Na}$ & 78.74 & $*$ & AUDPCs $=\mathrm{e}^{(1.02-4.68 / \mathrm{Na})}$ \\
\hline
\end{tabular}

y The six plant growth media were inoculated with Fusarium oxysporum f. sp. lycopersici race 2 at $1 \times 10^{5}$ microconidia $/ \mathrm{cm}^{3}$.

z Significance levels: *, **, and *** indicate $P<0.05,0.01$, and 0.001 , respectively.

TABLE 4. Nutrient availability of six plant growth media at the end of bioassay ${ }^{\mathrm{x}}$

\begin{tabular}{|c|c|c|c|c|c|c|c|c|c|c|}
\hline \multirow[b]{2}{*}{ Plant growth medium ${ }^{y}$} & \multicolumn{10}{|c|}{ Nutrient/growth medium $\left(\mathrm{mg} / \mathrm{cm}^{3}\right)^{\mathrm{z}}$} \\
\hline & $\mathrm{NO}^{3}$ & $\mathrm{P}$ & $\mathrm{K}$ & $\mathrm{Mg}$ & $\mathrm{Ca}$ & $\mathrm{Na}$ & $\mathrm{Fe}\left(10^{-2}\right)$ & $\mathrm{Cu}\left(10^{-2}\right)$ & $\mathrm{Zn}\left(10^{-2}\right)$ & $\operatorname{Mn}\left(10^{-2}\right)$ \\
\hline $\mathrm{CC}$ & $0.123 \mathrm{a}$ & $0.196 \mathrm{c}$ & $0.196 \mathrm{c}$ & $0.842 \mathrm{e}$ & $4.787 \mathrm{~b}$ & $0.139 \mathrm{~b}$ & $0.31 \mathrm{bc}$ & $0.02 \mathrm{~d}$ & $0.24 \mathrm{~b}$ & $0.86 \mathrm{~b}$ \\
\hline CC-60 & $0.085 \mathrm{ab}$ & $0.352 \mathrm{~b}$ & $0.352 \mathrm{~b}$ & $0.983 \mathrm{c}$ & $5.561 \mathrm{~b}$ & $0.136 \mathrm{~b}$ & $0.38 \mathrm{abc}$ & $0.05 \mathrm{c}$ & $0.42 \mathrm{a}$ & $1.96 \mathrm{a}$ \\
\hline $\mathrm{P}$ & $0.060 \mathrm{ab}$ & $0.189 \mathrm{c}$ & $0.189 \mathrm{c}$ & $0.643 \mathrm{f}$ & $2.595 \mathrm{c}$ & $0.078 \mathrm{c}$ & $0.19 \mathrm{~d}$ & $0.09 \mathrm{~b}$ & $0.10 \mathrm{~cd}$ & $0.13 \mathrm{c}$ \\
\hline V & $0.023 \mathrm{~b}$ & $0.059 \mathrm{~d}$ & $0.059 \mathrm{~d}$ & $0.895 \mathrm{~d}$ & $1.668 \mathrm{c}$ & $0.028 \mathrm{~d}$ & $0.28 \mathrm{~cd}$ & $0.14 \mathrm{a}$ & $0.05 \mathrm{~d}$ & $0.18 \mathrm{c}$ \\
\hline GMC & $0.025 \mathrm{~b}$ & $0.429 \mathrm{a}$ & $0.429 \mathrm{a}$ & $1.316 \mathrm{a}$ & $9.983 \mathrm{a}$ & $0.216 \mathrm{a}$ & $0.41 \mathrm{ab}$ & $0.01 \mathrm{~d}$ & $0.09 \mathrm{~cd}$ & $0.81 \mathrm{~b}$ \\
\hline GMC-60 & $0.025 \mathrm{~b}$ & $0.431 \mathrm{a}$ & $0.431 \mathrm{a}$ & $1.177 \mathrm{~b}$ & $9.462 \mathrm{a}$ & $0.201 \mathrm{a}$ & $0.44 \mathrm{a}$ & $0.01 \mathrm{~d}$ & $0.12 \mathrm{c}$ & $0.90 \mathrm{~b}$ \\
\hline
\end{tabular}

x Plant growth media were infested with Fusarium oxysporum f. sp. lycopersici race 2 at $1 \times 10^{5}$ microconidia/cm ${ }^{3}$.

y CC, composted cork; CC-60, heated composted cork; P, peat; V, vermiculite; GMC, grape marc compost; GMC-60, heated grape marc compost.

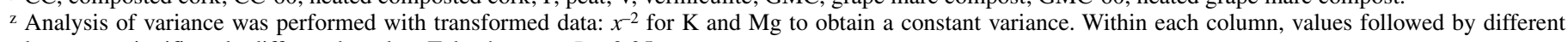
letters are significantly different based on Tukey's test at $P<0.05$.

TABLE 5. Nutrient status of tomato leaves and stems grown in six plant growth media at the end of bioassay ${ }^{\mathrm{x}}$

\begin{tabular}{|c|c|c|c|c|c|c|c|c|c|c|c|}
\hline \multirow[b]{2}{*}{ Medium $^{\mathrm{y}}$} & \multicolumn{11}{|c|}{ Nutrient/dry plant $(\mathrm{mg} / \mathrm{g})^{\mathrm{z}}$} \\
\hline & $\mathrm{N}$ & $\mathrm{P}$ & $\mathrm{K}$ & $\mathrm{Mg}$ & $\mathrm{Ca}$ & $\mathrm{Na}$ & $\mathrm{Fe}$ & $\mathrm{Cu}\left(10^{-2}\right)$ & $\mathrm{Zn}$ & $\mathrm{Mn}$ & $\mathrm{B}\left(10^{-2}\right)$ \\
\hline $\mathrm{CC}$ & $15.588 \mathrm{bc}$ & $21.106 \mathrm{bc}$ & $24.261 \mathrm{~cd}$ & $7.964 \mathrm{ab}$ & $31.398 \mathrm{a}$ & $1.931 \mathrm{~b}$ & $0.112 \mathrm{~cd}$ & $1.173 \mathrm{ab}$ & $0.071 \mathrm{bc}$ & $0.125 \mathrm{bc}$ & $4.129 \mathrm{~b}$ \\
\hline CC-60 & $17.248 \mathrm{abc}$ & $24.588 \mathrm{a}$ & $27.893 \mathrm{bc}$ & $6.110 \mathrm{~cd}$ & $31.237 \mathrm{a}$ & $1.930 \mathrm{~b}$ & $0.157 \mathrm{bc}$ & $1.601 \mathrm{a}$ & $0.127 \mathrm{a}$ & $0.306 \mathrm{a}$ & $4.469 \mathrm{ab}$ \\
\hline $\mathrm{P}$ & $22.775 \mathrm{a}$ & $24.567 \mathrm{a}$ & $22.483 \mathrm{~cd}$ & $4.590 \mathrm{~d}$ & $26.552 \mathrm{ab}$ & $2.030 \mathrm{~b}$ & $0.310 \mathrm{a}$ & $1.543 \mathrm{a}$ & $0.094 \mathrm{ab}$ & $0.120 \mathrm{bc}$ & $4.155 \mathrm{~b}$ \\
\hline V & $21.616 \mathrm{ab}$ & $23.235 \mathrm{ab}$ & $20.025 \mathrm{~d}$ & $8.953 \mathrm{a}$ & $22.076 \mathrm{~b}$ & $3.276 \mathrm{a}$ & $0.240 \mathrm{ab}$ & $1.806 \mathrm{a}$ & $0.062 \mathrm{c}$ & $0.103 \mathrm{c}$ & $4.208 \mathrm{ab}$ \\
\hline GMC & $9.728 \mathrm{~d}$ & $17.849 \mathrm{c}$ & $34.268 \mathrm{ab}$ & $7.176 \mathrm{bc}$ & $25.965 \mathrm{ab}$ & $1.166 \mathrm{c}$ & $0.093 \mathrm{~d}$ & $0.897 \mathrm{~b}$ & $0.072 \mathrm{bc}$ & $0.084 \mathrm{~d}$ & $4.155 \mathrm{~b}$ \\
\hline GMC-60 & $14.357 \mathrm{c}$ & $20.603 \mathrm{bc}$ & $41.617 \mathrm{a}$ & $7.133 \mathrm{bc}$ & $27.149 \mathrm{ab}$ & $1.507 \mathrm{bc}$ & $0.125 \mathrm{~cd}$ & $1.425 \mathrm{a}$ & $0.125 \mathrm{a}$ & $0.145 \mathrm{~b}$ & $4.704 \mathrm{a}$ \\
\hline
\end{tabular}

x Plant growth media were infested with Fusarium oxysporum f. sp. lycopersici race 2 at $1 \times 10^{5}$ microconidia/cm ${ }^{3}$.

y CC, composted cork; CC-60, heated composted cork; P, peat; V, vermiculite; GMC, grape marc compost; GMC-60, heated grape marc compost.

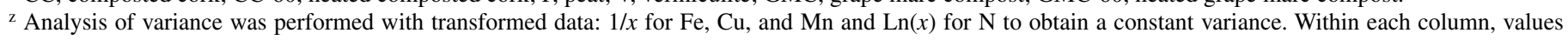
followed by different letters are significantly different based on Tukey's test at $P<0.05$. 
(7.97) at the beginning of the bioassays. The carbon source requirements of $F$. oxysporum have been identified (61). Availability of these carbon sources, and even the loss of endogenous reserves from chlamydospores of Fusarium spp., will depend on both their presence in the media and microbial competition for their use (35). The microbial activity of the media is an index related to competition $(20,60)$ and has provided meaningful insights into the microbial carrying capacity of organic soil with respect to the biological control of diseases caused by several soilborne plant pathogens sensitive to microbiostasis (5). Some Fusarium wilt-suppressive soils have been characterized for their high degree of microbiostasis derived from high microbial activity $(1,53)$. For the six plant growth media used in this study, when $\mathrm{pH}$ and $\beta$-glucosidase activity were taken into account as predictive variables (multiple linear regression), more than $91 \%$ of the variation in Fusarium wilt severity (as measured by AUDPCs) was explained $(P<0.05)$ (Fig. 2). The high correlation coefficient obtained from the integration of a chemical environment, such as $\mathrm{pH}$, and a microbial parameter, such as $\beta$-glucosidase activity, with respect to the occurrence of Fusarium wilt illustrates their importance in the growth media studied and their predictive potential.

The $\mathrm{pH}$ of plant growth medium, as a determinant of Fusarium wilt severity, is associated with the availability of macro- and micro-nutrients, important for either growth, sporulation, or virulence of F. oxysporum (28). In our study, there was a negative correlation between $\mathrm{Ca}$ availability and AUDPCs; this is consistent with other studies (28). The $\mathrm{pH}$ reduces the availability of nutrients such $\mathrm{P}, \mathrm{Mg}, \mathrm{Mn}, \mathrm{Cu}, \mathrm{Zn}$, and $\mathrm{Fe}$ in organic growth media (18), the pathogen being more vulnerable than the host plant (61). In this study, there was a significant positive correlation between AUDPCs and final availability in growth media of $\mathrm{Cu}$, and final nutrient status in plants of $\mathrm{Fe}, \mathrm{Cu}$, and $\mathrm{P}$. These results are consistent with the importance of $\mathrm{pH}$ as a chemical environmental index of Fusarium wilt in tomato $(2,11,28,61)$. In general, more disease is associated with higher rates of nitrogen application $(28,61)$. The correlations between $\mathrm{N}$ in plant tissue and AUDPCs are in agreement with the above-mentioned studies. In terms of the relationship between form of nitrogen (nitrates versus ammonia) and Fusarium wilt of tomato, several considerations should be noted: (i) daily fertigation was mostly with the ammonium form, (ii) the nitrification process was rapid in all growth media (data not shown), and (iii) the immobilization process by microorganisms was low and similar for the two studied composts (data not shown). Consequently, nitrogen source was a controlled variable in this study. High $\mathrm{Na}$ content in plants is associated with increased disease severity of Fusarium wilt in tomato (12). Sodium competes and replaces $\mathrm{Ca}$ ions of the polygalacturonate chains of the cell membrane, making the plant more susceptible to Fusarium wilt disease (29). In this study, the correlation between $\mathrm{Na}$ in plant tissue and AUDPCs was consistent with previous studies (12).

The stages of growth, decline, or persistence of a population of Fusarium in soil depend on the ecological balance and nutrient availability (61). The most critical limitation is chemical energy and competition for energy sources present in soil (33). Other microorganisms (bacteria, actinomycetes, and fungi) compete according to the magnitude of their genetically controlled reproductive capacity. Suppression of $F$. oxysporum by competitive microorganisms seems to be mainly due to depletion of available carbon sources, but also to antibiotic production (34). Furthermore, actinomycetes and bacterial populations are favored by high soil $\mathrm{pH}$ (58). For the growth media studied, at the end of bioassays a strong negative correlation between populations of different microorganisms and AUDPCs was found for cellulolytic actinomycetes and the ratio of cellulolytic actinomycetes/cellulolytic bacteria. These results are in agreement with the biological control of diseases in growth media formulated with stabilized organic components as determined by the microbial carrying capacity, this being dependent upon the concentration of slow release sources of nutrients for growth and activity such as carbohydrates (hemicellulose, cellulose, and so on) $(21,23)$. Boehm et

TABLE 8. Correlation (simple) among standardized area under the disease progress curve (AUDPCs) and different microorganisms recovered from growth media (CFU/ $\mathrm{cm}^{3}$ of plant growth medium)

\begin{tabular}{|c|c|c|c|}
\hline $\begin{array}{l}\text { Microorganism } \\
\text { group }^{y}\end{array}$ & $R^{2}$ & $P^{\mathrm{z}}$ & Equation \\
\hline $\mathrm{OA}$ & 99.31 & $* * *$ & AUDPCs $=1 /\left(2.8635+5.810^{-6} \cdot \mathrm{OA}\right)$ \\
\hline $\mathrm{OA} / \mathrm{OB}$ & 99.12 & $* * *$ & AUDPCs $=1 /(2.6899+2,586.12 \cdot \mathrm{OA} / \mathrm{OB})$ \\
\hline $\mathrm{CA}$ & 98.50 & $* * *$ & AUDPCs $=1 /\left(3.694+0.17210^{-3} \mathrm{CA}\right)$ \\
\hline $\mathrm{CA} / \mathrm{CB}$ & 98.50 & $* * *$ & AUDPCs $=1 /(3.6939+8,829.72 \cdot \mathrm{CA} / \mathrm{CB})$ \\
\hline $\mathrm{F}$ & 80.68 & $*$ & AUDPCs $=e^{(-0.6941-0.0000064 \cdot \mathrm{F})}$ \\
\hline $\mathrm{OB} / \mathrm{C}$ & 68.90 & $*$ & AUDPCs $=e^{(-0.7444-3.1961 \cdot \mathrm{OB} / \mathrm{C})}$ \\
\hline
\end{tabular}

y The six plant growth media were infested with Fusarium oxysporum f. sp. lycopersici race 2 at $1 \times 10^{5}$ microconidia $/ \mathrm{cm}^{3}$. OA $=$ oligotrophic actinomycetes, $\mathrm{OB}=$ oligotrophic bacteria, $\mathrm{CA}=$ cellulolytic actinomycetes, $\mathrm{CB}=$ cellulolytic bacteria, $\mathrm{F}=$ fungi, and $\mathrm{C}=$ copiotrophic bacteria.

${ }^{z}$ Significance levels: $*$, $* *$, and $* * *$ indicate $P<0.05,0.01$, and 0.001 , respectively.

TABLE 7. Microbiological properties of plant growth media at the end of the bioassay

\begin{tabular}{|c|c|c|c|c|c|c|c|c|}
\hline \multirow[b]{2}{*}{ Growth mediay } & \multicolumn{8}{|c|}{$\times 10^{5} \mathrm{CFU} / \mathrm{cm}^{3}$ of plant growth medium ${ }^{\mathrm{z}}$} \\
\hline & $\mathrm{CA}$ & $\mathrm{B}$ & $\mathrm{C}$ & FP & $\mathrm{CB}$ & $\mathrm{OA}$ & $\mathrm{OB}$ & $\mathrm{F}$ \\
\hline \multicolumn{9}{|l|}{ Controls } \\
\hline $\mathrm{CC}$ & $0.1120 \mathrm{ab}$ & $3.111 \mathrm{c}$ & $2,863 \mathrm{ab}$ & $16.17 \mathrm{a}$ & $336.3 \mathrm{ab}$ & $2.596 \mathrm{~b}$ & $1,329 \mathrm{a}$ & $0.3523 \mathrm{bc}$ \\
\hline CC-60 & $0 \mathrm{~b}$ & $33.63 \mathrm{~b}$ & $3,686 \mathrm{ab}$ & $0.0075 \mathrm{c}$ & $1,093 \mathrm{a}$ & $9.263 \mathrm{~b}$ & $3,519 \mathrm{a}$ & $1.993 \mathrm{ab}$ \\
\hline $\mathrm{P}$ & $0.0373 \mathrm{ab}$ & $0.122 \mathrm{~d}$ & $1,902 \mathrm{~b}$ & $0.0886 \mathrm{bc}$ & $227.5 \mathrm{ab}$ & $0.8007 \mathrm{c}$ & $504.1 \mathrm{a}$ & $1.574 \mathrm{ab}$ \\
\hline $\mathrm{V}$ & $0 \mathrm{~b}$ & $7.480 \mathrm{~d}$ & $5,956 \mathrm{ab}$ & $0.2689 \mathrm{bc}$ & $135.2 \mathrm{~b}$ & $0.0787 \mathrm{~d}$ & $2,299 \mathrm{a}$ & $0.5135 \mathrm{bc}$ \\
\hline GMC & $4.824 \mathrm{a}$ & $19.99 \mathrm{~b}$ & $3,781 \mathrm{ab}$ & $0.3026 \mathrm{~b}$ & $2,127 \mathrm{a}$ & $44.21 \mathrm{a}$ & $2,728 \mathrm{a}$ & $7.270 \mathrm{a}$ \\
\hline GMC-60 & ND & $137 \mathrm{a}$ & $9,225 \mathrm{a}$ & $0.0238 \mathrm{c}$ & $402.7 \mathrm{ab}$ & $2.878 \mathrm{~b}$ & $2,687 \mathrm{a}$ & $0.0923 \mathrm{c}$ \\
\hline \multicolumn{9}{|l|}{ Infested } \\
\hline $\mathrm{CC}$ & $0 \mathrm{~b}$ & $8.766 a b$ & 6,646 & $1.109 \mathrm{ab}$ & 1,083 & $2.651 \mathrm{~b}$ & 3,679 & $0.9636 \mathrm{~b}$ \\
\hline CC-60 & $0 \mathrm{~b}$ & $32.07 \mathrm{ab}$ & 9,311 & $0.7774 \mathrm{ab}$ & 688.0 & $1.354 \mathrm{~b}$ & 6,206 & $0.4951 \mathrm{~b}$ \\
\hline $\mathrm{P}$ & $0 \mathrm{~b}$ & $1.478 \mathrm{bc}$ & 4,526 & $0.0290 \mathrm{~b}$ & 671.4 & $1.082 \mathrm{~b}$ & 2,089 & $0.5765 \mathrm{~b}$ \\
\hline $\mathrm{V}$ & $0 \mathrm{~b}$ & $0.123 \mathrm{c}$ & 1,799 & $0.0638 \mathrm{ab}$ & 227.0 & $0.0023 \mathrm{c}$ & 1,377 & $0.2788 \mathrm{~b}$ \\
\hline GMC & $1.599 \mathrm{a}$ & $25.31 \mathrm{a}$ & 3,734 & $0.2308 \mathrm{ab}$ & 512.5 & $49.24 \mathrm{a}$ & 4,454 & $3.706 \mathrm{a}$ \\
\hline GMC-60 & $0 \mathrm{~b}$ & $90.62 \mathrm{a}$ & 5,494 & $2.5614 \mathrm{a}$ & 597.6 & $1.973 \mathrm{~b}$ & 4,201 & $2.434 \mathrm{~b}$ \\
\hline
\end{tabular}

${ }^{x}$ Control $=$ noninfested media and infested $=$ Fusarium oxysporum $\mathrm{f}$. sp. lycopersici race 2 at $1 \times 10^{5}$ microconidia $/ \mathrm{cm}^{3}$.

y CC, composted cork; CC-60, heated composted cork; P, peat; V, vermiculite; GMC, grape marc compost; GMC-60, heated grape marc compost.

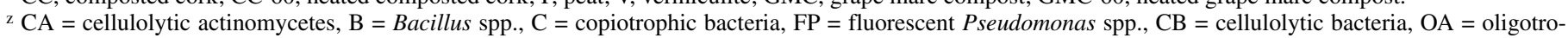
phic actinomycetes, $\mathrm{OB}=$ oligotrophic bacteria, $\mathrm{F}=$ fungi. Within each column of controls or infested media, values followed by different letters are significantly different based on Tukey's test at $P<0.05$. Analysis of variance was performed with transformed data in Ln $(x)$. For cellulolytic actinomycetes $(2 \mathrm{~m})^{-1}, \mathrm{~m}=$ number of replicate added to obtain normalized data. ND $=$ not determined. 
al. (5) have shown that the concentration of carbohydrates in a suppressive light peat mix decreases as suppressiveness is lost. Tuitert et al. (56) also found that high populations of cellulolytic actinomycetes and the ratio of cellulolytic actinomycetes/cellulolytic bacteria were able to differentiate between organic household waste composts which were conducive to or suppressive of Rhizoctonia solani. Workneh and Van Bruggen (62) also recorded positive correlations between the total number of actinomycetes and the proportion of cellulolytic ones with suppressiveness of soil to Pyrenochaeta lycopersici. Other strong negative correlations related to suppressive phenomena found in this study involved oligotrophic actinomycetes, oligotrophic actinomycetes/ oligotrophic bacteria, and oligotrophic bacteria/copiotrophic bacteria. Tuitert et al. (56) found higher oligotrophic populations in growth media that were suppressive of, rather than conducive to, $R$. solani. Ohta and Hatory (41) suggested that oligotroph life is associated with cellulose decomposers on organic debris. Our results regarding the negative correlation of fungal populations and AUDPCs also are in agreement with those for organic household waste composts suppressive of $R$. solani (56). On the other hand, Kuter et al. (32) found no differences in total numbers of fungi for hardwood bark composts that were suppressive and nonsuppressive of Rhizoctonia damping-off; however, there were quantitative differences in the relative abundance of certain taxa which separated suppressive from conducive media amended with hardwood bark compost. The high population densities of Bacillus spp. associated with the two composts, either natural or heated, may account for the suppressiveness in our composts. Similarly in a study on potting mix amended with chicken manure, high population densities of Bacillus spp. were associated with the survival of seedlings infested with Phytophthora cinnamomi (3). The high population densities of fluorescent Pseudomonas spp. in CC (controls) may be involved in the suppressiveness of this material $(2,14)$.

The community structures of the plant growth media studied were different at the beginning of the bioassays, based on CLPPs. The similar catabolic potential of CC microbial communities and FOL-2, together with the lower diversity index and the higher $\beta$ glucosidase activity and AODC microbial biomass, suggest a high competition for $\mathrm{C}$-sources. These results, along with the low level of disease suppression of heated CC, suggest that control is biological, and basically concerns competition between $F$. oxysporum and endogenous microbial communities. Although the high biological diversity found in vermiculite is noteworthy, its very low microbial activity and biomass should not be overlooked. The high diversity found for this inorganic material can be explained by the fact that vermiculite is almost totally sterile prior to use. The primary source of microorganisms in this medium probably is handling processes, although aerial transmission also may play a role (7). Higher diversity cannot explain disease control in this study, as evidenced by the Shannon diversity index between the conducive peat and the suppressive GMC and the lower 1-G and Shannon index of the suppressive CC with respect to peat. Thus, our results are in agreement with those of Boehm et al. (5) for control of Pythium root rot, but not with those of Nitta (39) or Toyota et al. (53), where lower diversity was associated with conduciveness to brown stem rot of bean and Fusarium wilt of radish, respectively.

In conclusion, the strong relationship found at the beginning of the bioassays for AUDPCs with $\mathrm{pH}$ of growth media and $\beta$-glucosidase activity of microbial populations supports its predictive value. The $\mathrm{pH}$ reflected the availability of inorganic nutrients in this multiple correlation. For Fusarium wilt control, the importance of availability of specific nutrients is demonstrated by fertility management (28) and by the biocontrol induced for Fe competition by fluorescent Pseudomonas spp. $(2,14)$. Based on our results, microbial competition (measured as $\beta$-glucosidase activity), especially for the $\mathrm{C}$-source present in the media and root exudates
$(33,38,60)$, plays a significant role in disease suppression. The microbial community acts as a nutrient sink that is independent of the microbial community structure in this study. Future research may provide additional information that would allow us to generalize the relationships between $\mathrm{pH}$ and $\beta$-glucosidase activity as predictive variables for the suppressiveness of other growth media and other Fusarium wilt diseases.

\section{ACKNOWLEDGMENTS}

This research was supported by grant IFD97-1322-C04 from the Comisión Interministerial de Ciencia y Tecnología (Proyectos I+D del Programa FEDER) and by grant AGL2002-04313-C03 from the Ministerio de Ciencia y Tecnología (Proyectos I+D del Plant Nacional de Investigación Científica, Desarrollo e Innovación Tecnológica) of Spain. We thank S. Castillo, M. C. Mauri, and M. J. Infantes for excellent technical assistance; and H. A. J. Hoitink for reviewing the manuscript.

\section{LITERATURE CITED}

1. Alabouvette, C. 1986. Fusarium-wilt suppressive soils from the Châteaurenard region: Review of a 10-year study. Agronomie 6:273-284.

2. Alabouvette, C., Hoeper, H., Lemanceau, P., and Steinberg, C. 1996. Soil suppressiveness to diseases induced by soilborne plant pathogens. Pages 371-413 in: Soil Biochemistry, Vol. 9. G. Stotzky and J. M. Bollag, eds. Marcel Dekker, Inc., New York.

3. Aryantha, I. P., Cross, R., and Guest, D. I. 2000. Suppression of Phytophthora cinnamomi in potting mixes amended with uncomposted and composted animal manures. Phytopathology 90:775-782.

4. Bandick, A. K., and Dick, R. P. 1999. Field management effects on soil enzyme activities. Soil Biol. Biochem. 31:1471-1479.

5. Boehm, M. J., Wu, T., Stone, A. G., Kraakman, B., Iannotti, D. A., Wilson, G. E., Madden, L. V., and Hoitink, H. A. J. 1996. Cross-Polarized magic-angle spinning ${ }^{13} \mathrm{C}$ nuclear magnetic resonance spectroscopic characterization of soil organic matter relative to culturable bacterial species composition and sustained biological control of Pythium root rot. Appl. Environ. Microbiol. 63:162-168.

6. Bunt, A. C. 1988. Media and Mixes for Container-Grown Plants: A Manual on the Preparation and Use of Growing Media for Pot Plants. 2nd ed. Academic Division of Unwin Hyman Ltd., London.

7. Carlile, W. R., and Wilson, D. P. 1991. Microbial activity in growing media - A brief review. Acta Hortic. 294:197-206.

8. Cebolla, V., and Pera, J. 1983. Suppressive effects of certain soils and substrates against Fusarium wilt of carnation. Acta Hortic. 150:113-119.

9. Chef, D. G., Hoitink, H. A. J., and Madden, L. V. 1983. Effects of organic components in container media on suppression of Fusarium wilt of chrysanthemum and flax. Phytopathology 73:279-281.

10. Chen, W., Hoitink, H. A. J, Schmitthenner, A. F., and Tuovinen, O. H. 1988. The role of microbial activity in suppression of damping-off caused by Pythium ultimum. Phytopathology 78:314-322.

11. Cotxarrera, L., Trillas-Gay, M. I., Steinberg, C., and Alabouvette, C. 2002. Use of sewage sludge compost and Trichoderma asperellum isolates to suppress Fusarium wilt of tomato. Soil Biol. Biochem. 34:467-476.

12. Davet, P., Messiaen, C. M., and Rieuf, P. 1966. Interpretation des manifestations hivernales de la fusariose de la tomate en Afrique du nord, favorisées par la presence de sels dan les eaux d'irrigation. Pages 407416 in: Proc. First Congr. Mediterr. Phytopathol. Union, Bari-Naples, Italy.

13. De Boodt, M., Verdonk, O., and Cappaert, I. 1974. Method for measuring the water release curve of organic substrates. Acta Hortic. 37:20542062.

14. Duijff, B. J., Meijer, J. W., Bakker, P. A. H. M., and Schippers, B. 1993 Siderophore-mediated competition for iron and induced resistance in the suppression of Fusarium wilt of carnation by fluorescent Pseudomonas spp. Neth. J. Plant Pathol. 99:277-289.

15. Gabriëls, R., Van Keirsbulck, W., and Verdonck, O. 1991. Reference method for physical and chemical characterization of growing media: An international comparative study. Acta Hortic. 294:147-160.

16. Garibaldi, A. 1988. Research on substrates suppressive to Fusarium oxysporum and Rhizoctonia solani. Acta Hortic. 221:271-277.

17. Glimm, E., Heuer, H., Engelen, B., Smalla, K., and Backhaus, H. 1997. Statistical comparisons of community catabolic profiles. J. Microbiol. Methods 30:71-80.

18. Handreck, K., and Black, N. 1991. Growing Media for Ornamental Plants and Turf. New South Wales University Press, Kensington, Australia.

19. Harch, B. D., Correll, R. L., Meech, W., Kirkby, C. A., and Pankhurst, C. E. 1997. Using the Gini coefficient with BIOLOG substrate utilisation 
data to provide an alternative quantitative measure for comparing bacterial soil communities. J. Microbiol. Methods 30:91-101.

20. Hoitink, H. A. J., and Boehm, M. J. 1999. Biocontrol within the context of soil microbial communities: A substrate-dependent phenomenon. Annu. Rev. Phytopathol. 37:427-446.

21. Hoitink, H. A. J., Boehm, M. J., and Hadar, Y. 1993. Mechanisms of suppression of soilborne plant pathogens in compost-amended substrates. Pages 601-621 in: Science and Engineering of Composting: Design, Environmental, Microbiological and Utilization Aspects. H. A. J. Hoitink and H. M. Keener, eds. Renaissance Publications, Worthington, $\mathrm{OH}$.

22. Hoitink, H. A. J., Inbar, Y., and Boehm, M. J. 1991. Status of compostamended potting mixes naturally suppressive to soilborne diseases of floricultural crops. Plant Dis. 75:869-873.

23. Hoitink, H. A. J., Madden, L. V., and Boehm, M. J. 1996. Relationships among organic matter decomposition level, microbial species diversity and soilborne disease severity. Pages 237-249 in: Principles and Practice of Managing Soilborne Plant Pathogens. R. Hall, ed. The American Phytopathological Society, St. Paul, MN.

24. Howard, P. J. A. 1999. Analysis of inter-sample distances from BIOLOG plate data in Euclidean and simplex spaces. Soil Biol. Biochem. 31:13231330.

25. Insam, H. 1997. A new set of substrates proposed for community characterization in environmental samples. Page 259 in: Microbial Communities. Functional Versus Structural Approaches. H. Insam and A. Rangger, eds. Springer, Heidelberg, Germany.

26. Insam, H., Amor, K., Renner, M., and Crepaz, C. 1996. Changes in functional abilities of the microbial community during composting of manure. Microbial Ecol. 31:77-87.

27. Jones, J. B., Jones, J. P., Stall, R. E., and Zitter, T. A., eds. 1991. Compendium of Tomato Diseases. The American Phytopathological Society, St. Paul, MN.

28. Jones, J. P., Engelhard, A. W., and Woltz, S. S. 1993. Management of Fusarium wilt of vegetables and ornamentals by macro- and microelement nutrition. Pages 18-32 in: Soilborne Plant Pathogens: Management of Diseases with Macro- and Microelements. W. A. Engelhard, ed. The American Phytopathological Society, St. Paul, MN

29. Jones, J. P., and Woltz, S. S. 1981. Fusarium-incited diseases of tomato and potato and their control. Pages 157-168 in: Fusarium: Diseases, Biology and Taxonomy. P. E. Nelson, T. A. Toussoun, and R. J. Cook, eds. Pennsylvania State University Press, University Park.

30. Kepner, R. L., Jr., and Pratt, J. R. 1994. Use of fluorochromes for direct enumeration of total bacterial in environmental samples: Past and present. Microbiol. Rev. 58:603-615.

31. Keren, R. 1996. Boron. Pages 603-626 in: Methods of Soil Analysis. D. L. Sparks, ed. Soil Science Society of America, Inc., Madison, WI.

32. Kuter, G. A., Nelson, E. B., Hoitink, H. A. J., and Madden, L. V. 1983. Fungal populations in container media amended with composted hardwood bark suppressive and conducive to Rhizoctonia damping-off. Phytopathology 73:1450-1456.

33. Lockwood, J. L. 1988. Evolution of concepts associated with soilborne plant pathogens. Annu. Rev. Phytopathol. 26:93-121.

34. Marshall, K. C., and Alexander, M. 1960. Competition between soil bacteria and Fusarium. Plant Soil 12:143-148.

35. Mondal, S. N., Kagejama, K., and Hyakumachi, M. 1995. Germinability, viability, and virulence of chlamydospores of Fusarium solani f. sp. phaseoli as affected by the loss of endogenous carbon. Phytopathology 85:1238-1244.

36. Mulvaney, R. L. 1996. Nitrogen-inorganic forms. Pages 123-1184 in: Methods of Soil Analysis. D. L. Sparks, ed. Soil Science Society of America, Inc., Madison, WI.

37. Murphy, J., and Riley, J. P. 1962. A modified single solution method for the determination of phosphate in natural waters. Anal. Chim. Acta 27:3136.

38. Nelson, E. B. 1990. Exudate molecules initiating fungal responses to seeds and roots. Plant Soil 129:61-73.

39. Nitta, T. 1991. Diversity of root fungal floras: Its implications for soilborne diseases and crop growth. JARQ Jpn. Agric. Res. Q. 25:6-11.

40. Nogués, S., Cotxarrera, L., Alegre, L., and Trillas, M. I. 2002. Limitations to photosynthesis in tomato leaves induced by Fusarium wilt. New Phytol. 154:461-470.
41. Ohta, H., and Hattori, T. 1983. Oligotrophic bacteria in organic debris and plant roots in a paddy field soil. Soil Biol. Biochem. 15:1-8.

42. Orlikowski, L. B. 1983. Influence of substratum type and fungicidal treatment on the development of Fusarium wilt of carnation. Acta Hortic. 150:127-139.

43. Pera, A., and Filippi, C. 1987. Controlling of Fusarium wilt in carnation with bark compost. Biol. Wastes 22:219-228.

44. Pera, J., and Calvet, C. 1989. Suppression of Fusarium wilt of carnation in a composted pine bark and composted olive pumice. Plant Dis. 73:699700 .

45. Reuveni, R., Raviv, M., Krasnovsky, A., Freiman, L., Medina, S., Bar, A., and Orion, D. 2002. Compost induces protection against Fusarium oxysporum in sweet basil. Crop Prot. 21:583-587.

46. Rice, W. C., Moorman, B. T., and Beare, M. 1996. Role of microbial biomass carbon and nitrogen and soil quality. Pages 203-215 in: Methods for Assessing Soil Quality. D. L. Sparks, ed. Soil Science Society of America, Inc., Madison, WI.

47. Serra-Wittling, C., Houot, S., and Alabouvette, C. 1996. Increased soil suppressiveness to Fusarium wilt of flax after addition of municipal solid waste compost. Soil Biol. Biochem. 28:1207-1214.

48. Shannon, C. E., and Weaver, W. 1949. The Mathematical Theory of Communication. University of Illinois Press, Urbana.

49. Sharma, S., Piccolo, A., and Insam, H. 1997. Different carbon source utilization profiles of four tropical soils from Ethiopia. Pages 132-140 in: Microbial Communities. Functional Versus Structural Approaches. H. Insam and A. Rangger, eds. Springer, Heidelberg, Germany.

50. Sharman, K. V., and Whitehouse, M. 1993. Nitrogen drawdown index as a predictor of nitrogen requirements for Nephrolepis in sawdust media. Sci. Hortic. (Amsterdam) 54:32-33.

51. Szczech, M. M. 1999. Suppressiveness of vermicompost against Fusarium wilt of tomato. J. Phytopathol. 147:155-161.

52. Szczech, M., Rondomanski, W., Brzeski, M. W., Smolinska, U., and Kotowski, J. F. 1993. Suppressive effect of a commercial earthworm compost on some root infecting pathogens of cabbage and tomato. Biol. Agric. Hortic. 10:47-52.

53. Toyota, K., Kimura, M., Takechi, S., and Kuninaga, S. 2000. Comparison of microbial community structure between soils suppressive and conducive to Fusarium-wilt of radish. Soil Microorg. 54:69-79.

54. Trillas, I., Avilés, M., Ordovás, J., Bello, A., and Tello, J. C. 2002. Using compost as a methyl bromide alternative. Biocycle 43:64-68.

55. Trillas-Gay, M. I., Hoitink, H. A. J., and Madden, L. V. 1986. Nature of suppression of Fusarium wilt of radish in a container medium amended with composted hardwood bark. Plant Dis. 70:1023-1027.

56. Tuitert, G., Szczech, M., and Bollen, G. J. 1998. Suppression of Rhizoctonia solani in potting mixtures amended with compost made from organic household waste. Phytopathology 88:764-773.

57. Van Veldhoven, P. P., and Mannaerts, G. P. 1987. Inorganic and organic phosphate measurements in the nanomolar range. Anal. Biochem. $161: 45-48$

58. Waksman, S. A. 1927. Principles of Soil Microbiology. The Williams and Wilkins Co., Baltimore, MD.

59. Warrior, P., Konduru, K., and Vasudevan, P. 2002. Formulation of biological control agents for pest and disease management. Pages 421-441 in: Biological Control of Crops Diseases. S. S. Gnanamanickam, ed. Marcel Decker, Inc., New York.

60. Weller, D. M., Raaijmakers, J. M., McSpadden Gardener, B. B., and Thomashow, L. S. 2002. Microbial populations responsible for specific soil suppressiveness to plant pathogens. Annu. Rev. Phytopathol. 40:309348.

61. Woltz, S. S., and Jones, J. P. 1981. Nutritional requirements of Fusarium oxysporum: Basis for a disease control system. Pages 340-349 in: Fusarium: Diseases, Biology, and Taxonomy. P. E. Nelson, T. A. Toussoun, and R. J. Cook, eds. Pennsylvania State University Press, University Park.

62. Workneh, F., and van Bruggen, A. H. C. 1994. Microbial density, composition, and diversity in organically and conventionally managed rhizosphere soil in relation to suppression of corky root of tomatoes. Appl. Soil Ecol. 1:219-230.

63. Wright, R. J., and Stuczynski, T. 1996. Atomic absorption and flame emission spectrometry. Pages 65-90 in: Methods of Soil Analysis. D. L. Sparks, ed. Soil Science Society of America, Inc., Madison, WI. 